\title{
Penerapan Metode Technometrik Untuk Penilaian Kapabilitas Teknologi Industri Galangan Kapal Dalam Menyongsong Era Industri 4.0
}

\author{
Satrio Utomo ${ }^{1}$, Nugraheni Setiastuti ${ }^{2}$ \\ Pusat Pengkajian Industri Manufaktur,Telematika Dan Elektronika \\ Kedeputian Pengkajian Kebijakan Teknologi - BPPT \\ e-Mail : satrioutomo2005@yahoo.com, setiastutinugraheni@yahoo.com
}

\begin{abstract}
The national shipyard industry is one of the strategic and competitive industries that deserve to be developed. The current developing era, namely the industrial 4.0, the growth of the national shipyard industry is expected to be able to active in the era of industry 4.0. In certain aspects and scales, the capabilities possessed are not inferior to world-class capabilities, but further development is still needed, referring to the fact that many domestikfleet needs and repairs are still dependent on foreign shipyards. So far, the domestic shipyard industry still facing a number of challenges, including financial support from the financial sector. Therefore measurement is needed toincrease rationalization towards labor productivity. The objective of reseach was first, identify and evaluate the operation of the current national shipyard industry by assessing the level of shipyard technology. Second, to know the strengths and weakness of technology so that management can know which technology development priorities must first be given attention andimprovement an effort to meet the industrial 4.0. The technology capability level can be determined based on the TCC (Technology Contribution Coefficient) which is a Technometrics method developed by UN-ESCAP. Based on the results of the assessment is the level of shipyard technology of PT. DOK Kodja Bahari based on Technoware, Humanware, Infoware, and Orgaware components is 0.519 which shows a good classification at the level of semi-modern technology.
\end{abstract}

Keywords: industry 4.0, technoware, humanware, infoware, orgaware

\begin{abstract}
Abstrak
Industri galangan kapal merupakan industri dalam negeri yang strategis dan kompetitif yang patut untuk dikembangkan. Sejalan dengan era yang berkembang saat ini, maka perkembangan industri galangan kapal nasional diharapkan turut menyambut era generasi ke-empat atau revolusi industri 4.0. Sampai saat ini, industri galangan kapal masih menghadapi tantangan dan permasalahan. Oleh karena itu perlu pengukuran untuk meningkatkan rasionalisasi ke arah produktivitas tenaga kerja. Tujuan penelitian adalah pertama, melakukan penilaian tingkat kapabilitas teknologi galangan kapal. Kedua, mengetahui kelebihan dan kelemahan kapabilitas teknologi sehingga dapat mengetahui prioritas pengembangan teknologi mana yang harus terlebih dahulu yang mendapat perhatian dan perbaikan dalam upaya menyambut era industri 4.0. Tingkat kapabilitas teknologi ditentukan berdasar nilai TCC (TCC = Technology Constributon Coefficient). TCC merupakan metode Technometrik dari UN-ESCAP. Hasil dari Penilaian tingkat kapabilitas teknologi industri galangan kapal PT. Dok Kodja Bahari berdasar komponen Technoware, Humanware, Infoware, dan Orgaware adalah 0,519; berada di interval 0,5 < TCC <= 0.7 sehingga diklasifikasikan Baik pada tingkat teknologi adalah semi modern.
\end{abstract}

Kata kunci : industri 4.0, technoware, humanware, infoware, orgaware 


\section{PENDAHULUAN}

Saat ini kemajuan teknologi terutama di sektor industri sangat pesat, yang ditandai munculnya revolusi industri generasi keempat atau dikenal sebagai Revolusi Industri 4.0, dimana industri mampu mengintegrasikan produk yang dihasilkan dengan teknologi otomatisasi tinggi yang ditopang infrastruktur berbasis internet. Di era industri ke-4 ini, industri galangan kapal menjadi salah satu bagian industri manufaktur berperan penting dan dapat berkontribusi terhadap perekonomian nasional. Pemerintah menempatkan industri galangan kapal menjadi salah satu sektor industri yang diprioritaskan pengembangannya. Industri galangan kapal menjadi dasar pondasi untuk mendukung suksesnya program poros maritim maupun tol laut [1].

Sebagai industri kemaritiman, industri galangan kapal sangat perlu didorong menjadi industri unggulan sekaligus berdaya saing. Industri galangan kapal adalah salah satu industri yang mampu menyerap tenaga kerja dalam jumlah besar, padat modal serta padat teknologi, akan tetapi secara fakta menunjukkan banyak industri galangan dalam negeri khususnya industri galangan yang berstatus BUMN mengalami keterpurukan. Industri galangan kapal dewasa ini belum berkembang sesuai dengan tantangan yang dihadapi. Perkembangan yang terjadi masih jauh dari potensi, kapasitas, kebutuhan kapal dan tuntutan permintaan pasar [2].

Teknologi industri galangan kapal juga belum mengalami kemajuan.Hal tersebut terlihat bahwa industri galangan kapal yang ada masih belum mandiri, masih bergantung impor kapal dan mesin kapal dari negara lain seperti Jepang, Korea, Taiwan dan Malaysia. Harga produksi galangan kapal dalam negeri yang lebih tinggi 10 sampai 30 persen dari produk asing atau impor dan waktu produksi relatif lebih lama serta minimnya dukungan industri komponen dan penunjang lainnya merupakan hambatan industri galangan kapal saat ini [3].

Saat ini terdapat 240 perusahaan galangan dalam negeri, yang sebagian besar adalah galangan kapal dalam skala kecil dan 4 buah galangan kapal milik pemerintah yaitu: PT Dok \& Perkapalan Kodja Bahari, PT PAL Indonesia, PT Dok dan Perkapalan Surabaya dan PT Industri Kapal Indonesia [4]. Saat ini PT (PERSERO) Dok \& Perkapalan Kodja Bahari merupakan salah satu industri galangan kapal dalam negeri yang mempunyai kapabilitas tidak kalah dengan kapal luar negeri. Dibutuhkan program pembinaan dan pengembangan secara terfokus sehingga akan mampu meningkatkan daya saing di tingkat global. Perusahaan ingin mengembangkan strategi bisnis baru di industri marine untuk meningkatkan profitabilitas dan berkompetisi dengan pesaing. Tujuan penelitian adalah Mengetahui penilaian tingkat kapabilitas teknologi galangan kapal berdasarkan komponen teknologi yaitu Technoware, Humanware, Infoware dan Orgaware dan mengetahui peta kekuatan dan kelemahan kapabilitas teknologi yang diterapkan sehingga dapat mengetahui prioritas pengembangan teknologi mana yang harus 
terlebih dahulu yang mendapat perhatian dan perbaikan dalam upaya industri galangan kapal menyongsong era industri 4.0.

\section{METODOLOGI PENELITIAN}

Untuk mengetahui kemampuan perusahaan mengimplementasikan teknologi salah satunya adalah memahami kinerja suatu teknologi. Dengan mengambil kajian permasalahan di PT (PERSERO) Dok dan Perkapalan Kodja Bahari yang berlokasi di Jakarta Utara sebagai salah satu industry perkapalan dalam negeri. Untuk dapat mengidentifikasi tingkat muatan teknologi yang digunakan dan pemetaan permasalahan menggunakan metode Technometric yang dikembangkan UN-ESCAP (The United Nations Economic and Social Commission for Asia and the Pacific), yaitu: Technoware (Ketersediaan Fasilitas), Humanware (Kemampuan Sumber Daya Manusia), Infoware (Data dan Informasi), dan Orgaware (Manajemen Organisasi) [5].

Berdasar metode Technometric, langkah penilaian kapabilitas teknologi pada Industri galangan Kapal di PT. Dok Bahari Kodja, yaitu:

1. Estimasi level kecanggihan komponen teknologi (sofistikasi teknologi).

2. Penentuan tingkat kemutakhiran komponen teknologi

3. Penghitungan kontribusi komponen teknologi.

4. Penghitungan intensitas kontribusi komponen teknologi.

5. Penilaian koefisien kontribusi teknologi (TCC)

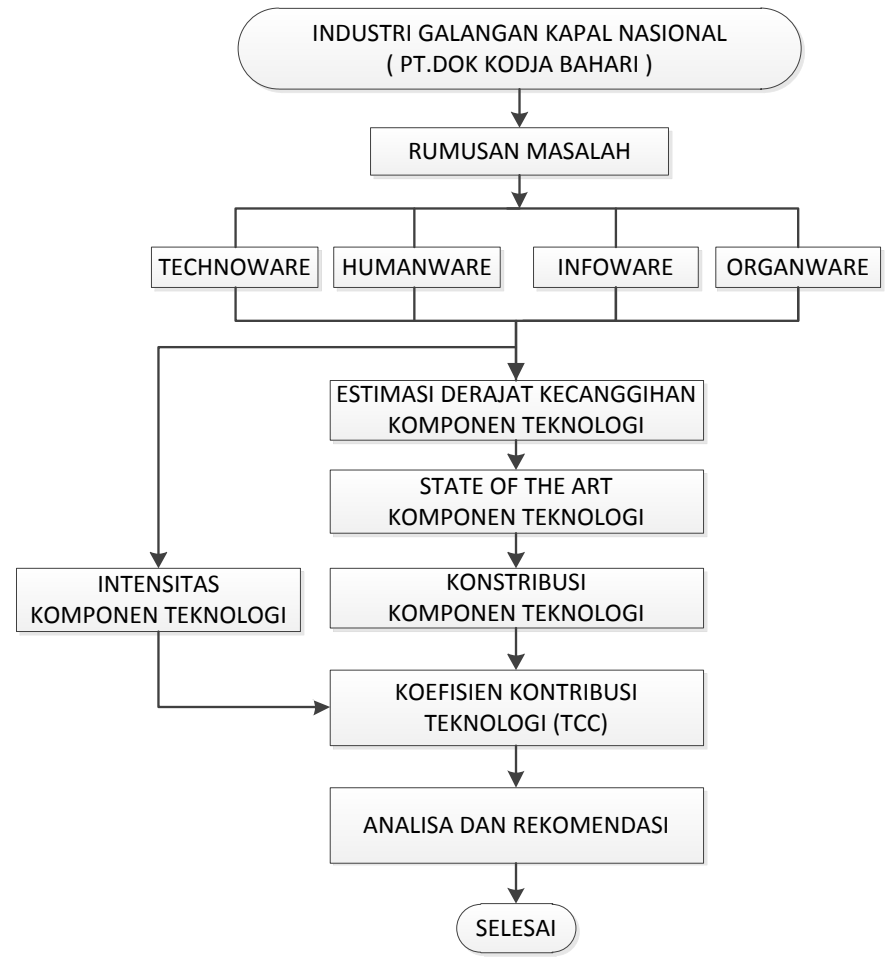

Gambar 1. Diagram FlowChart 


\subsection{Estimasi Level Kecanggihan Komponen Teknologi}

Estimasi level kecanggihan komponen teknologi dilakukan dengan mengacu kerangka dari UN-ESCAP. Setiap komponen teknologi harus ditentukan nilai batas bawah dan batas atas. Level kecanggihan komponen teknologi berdasar skala penilaian 1 sampai 9 [5].

Tabel 1 Kriteria dalam level kecanggihan komponen teknologi

\begin{tabular}{|c|c|c|c|c|c|c|}
\hline \multirow{2}{*}{ Technoware } & \multirow{2}{*}{ Humanware } & \multirow{2}{*}{ Infoware } & \multirow{2}{*}{ Orgaware } & \multicolumn{3}{|c|}{ Batas Nilai } \\
\hline & & & & Bawah & & Atas \\
\hline $\begin{array}{c}\text { Manual } \\
\text { Facilities }\end{array}$ & Operating Abilities & $\begin{array}{l}\text { Familianzing } \\
\text { Facts }\end{array}$ & $\begin{array}{l}\text { Striving } \\
\text { Framework }\end{array}$ & 1 & 2 & 3 \\
\hline Power Facilities & Setting-Up Abilities & Describing Facts & $\begin{array}{c}\text { Tie-Up } \\
\text { Framework }\end{array}$ & 2 & 3 & 4 \\
\hline $\begin{array}{c}\text { General Purpose } \\
\text { Facilities }\end{array}$ & Repairing Abilities & Specifying Fact & $\begin{array}{c}\text { Venturing } \\
\text { Frameworks }\end{array}$ & 3 & 4 & 5 \\
\hline $\begin{array}{c}\text { Special Purpose } \\
\text { Facilities }\end{array}$ & Reproducing Abilities & Utilizing Facts & $\begin{array}{c}\text { Protecting } \\
\text { Frameworks }\end{array}$ & 4 & 5 & 6 \\
\hline $\begin{array}{c}\text { Automatic } \\
\text { Facilities }\end{array}$ & Adaptation Abilities & $\begin{array}{l}\text { Comprehending } \\
\text { Facts }\end{array}$ & $\begin{array}{c}\text { Stabiling } \\
\text { Frameworks }\end{array}$ & 5 & 6 & 7 \\
\hline $\begin{array}{c}\text { Computerized } \\
\text { Facilities }\end{array}$ & Improving Abilities & $\begin{array}{l}\text { Generalizing } \\
\text { Facts }\end{array}$ & $\begin{array}{l}\text { Prospecting } \\
\text { Framework }\end{array}$ & 6 & 7 & 8 \\
\hline $\begin{array}{c}\text { Integrated } \\
\text { Facilities }\end{array}$ & Innovation Abililities & Assessing Facts & $\begin{array}{l}\text { Leading } \\
\text { Frameworks }\end{array}$ & 7 & 8 & 9 \\
\hline
\end{tabular}

Sumber: UN-ESCAP

\subsection{Penilaian Tingkat Kemutakhiran Komponen Teknologi (State of the Art)}

State of the Art adalah upaya melakukan penilaian tingkat kompleksitas dari masing-masing komponen teknologi. Penentuan status kecanggihan komponen teknologi membutuhkan input yang dipertimbangkan oleh teknisi, dan spesialis lainnya yang mengetahui secara baik aspek operasional. Berdasar indikator kriteria dari UN-ESCAP kemudian dikembangkan variabel kriteria sesuai dengan komponen indikator tersebut. Selanjutnya ditentukan kriteria spesifik yang terukur. Setiap kriteria diberikan nilai skala 0 - 10, dimana nilai 0 (nol) untuk spesifikasi terendah dan nilai 10 (sepuluh) untuk spesifikasi terbaik. Bila penilaian tidak tertera di acuan, maka dilakukan interpolasi nilai atas dan bawahnya [6]. Berikut rumus penilaian State of the Art sebagai berikut :

$$
\mathrm{S}=\frac{1}{10}\left[\frac{\sum k t_{i k}}{k t}\right] ; \mathrm{k}=1,2,3, \ldots, \mathrm{kt}
$$

Dimana:

S : State of The Art

$\mathrm{t}_{i k}$ : Nilai kriteria ke-k dari komponen teknologi.

$\mathrm{k} t$ : Jumlah variabel kriteria komponen teknologi 
Tabel 2. Indikator penilaian tingkat kemutakhiran komponen teknologi

\begin{tabular}{|c|c|c|c|c|}
\hline No & Technoware & Humanware & Infoware & Orgaware \\
\hline 1 & Kompleksitas operasi & Kreatifitas & $\begin{array}{c}\text { Kemudahan } \\
\text { pengulangan informasi }\end{array}$ & $\begin{array}{c}\text { Efektivitas } \\
\text { Kepemimpinan }\end{array}$ \\
\hline 2 & $\begin{array}{c}\text { Presisi / tingkat } \\
\text { ketelitian }\end{array}$ & $\begin{array}{c}\text { Orientasi } \\
\text { berprestasi }\end{array}$ & Keterkaitan & $\begin{array}{c}\text { Otonomi } \\
\text { pekerjaan }\end{array}$ \\
\hline 3 & Penanganan bahan & Teamwork & $\begin{array}{c}\text { Sistem pengolahan } \\
\text { data }\end{array}$ & Arah Organisasi \\
\hline 5 & Pengendalian proses & $\begin{array}{c}\text { Orientasi } \\
\text { produktifitas }\end{array}$ & $\begin{array}{c}\text { Kemudahan } \\
\text { mengkomunikasikan }\end{array}$ & $\begin{array}{c}\text { Keterlibatan } \\
\text { organisasional }\end{array}$ \\
\hline 6 & $\begin{array}{c}\text { Kontribusi fasilitas } \\
\text { rekayasa operasional }\end{array}$ & $\begin{array}{c}\text { Kemampuan } \\
\text { menghadapi } \\
\text { resiko }\end{array}$ & $\begin{array}{c}\text { Prosedur suatu } \\
\text { operasional }\end{array}$ & $\begin{array}{c}\text { Iklim inovasi } \\
\text { dalam organisasi }\end{array}$ \\
\hline image/citra & $\begin{array}{c}\text { Tanggung jawab } \\
\text { dan kedisiplinan }\end{array}$ & $\begin{array}{c}\text { Kecepatan akses } \\
\text { informasi }\end{array}$ & $\begin{array}{c}\text { Integritas } \\
\text { tindakan } \\
\text { organisasi }\end{array}$ \\
\hline
\end{tabular}

Sumber : UN-ESCAP

\subsection{Penentuan Kontribusi Komponen Teknologi}

Nilai kontribusi merupakan nilai yang dapat digunakan untuk menduga besarnya kontribusi masing-masing komponen teknologi terhadap nilai TCC.

Berikut penilaian konstribusi komponen Teknologi : [5]

$$
\begin{aligned}
& T=\frac{1}{9}[L T+S T(U T-L T)] \\
& H=\frac{1}{9}[L H+S H(U H-L H)] \\
& I=\frac{1}{9}[L I+S I(U I-L I)] \\
& O=\frac{1}{9}[L O+S O(U O-L O)]
\end{aligned}
$$

Keterangan :

$L T, L H, L I, L O=$ Batas bawah Technoware, Humanware, Inforware, Orgaware $U T, U H, U I, U O=$ Batas atas Technoware, Humanware, Inforware, Orgaware ST, SH, SI, SO = State of the Art Technoware, Humanware, Inforware, Orgaware

\subsection{Penghitungan Intensitas Kontribusi dari Komponen Teknologi ( $\beta$ )}

Intensitas kontribusi komponen untuk menilai tingkat kepentingan dari komponen teknologi dalam proses tranformasi. Data intensitas kontribusi komponen teknologi didapat dari responden ahli mengenai tingkat kepentingan komponen berdasar apa yang dirasakan tentang kondisi eksisting dan tingkat kepentingan terkait komponen teknologi [5]. Data intensitas konstribusi komponen teknologi cukup membandingkan tingkat kepentingan antara kriteria A dengan B. selanjutnya data diproses menggunakan aplikasi Software Expert Choice; Software berbasis OS Windows menggunakan metode AHP (Analytical Hierarcy Process). Metode AHP tidak melihat pada jumlah sampel besar tapi cukup expert atau informan terpilih yang mempunyai peranan dan mengetahui dengan baik bidang yang jadi objek penelitian [7]. 


\subsection{Penentuan Koefisien Kontribusi Teknologi (TCC)}

TCC merupakan metode Technometric yang bertujuan mengukur kontribusi hasil penggabungan ke-empat komponen teknologi. Tingkat teknologi ditentukan berdasarkan nilai TCC. Tingkat teknologi dapat dinilai berdasar nilai TCC [5].

$\mathrm{TCC}=\mathrm{T}^{\beta \mathrm{t}} \cdot \mathrm{H}^{\beta \mathrm{h}} . \mathrm{I}^{\beta \mathrm{i}} \cdot \mathrm{O}^{\beta \mathrm{o}}$

Dimana :

TCC = Technology Contribution Coefficient

$\mathrm{T}, \mathrm{H}, \mathrm{I}, \mathrm{O}=$ kontribusi komponen teknologi

$\beta \mathrm{t}, \beta \mathrm{h}, \beta \mathrm{i}, \beta \mathrm{o}=$ Intensitas kontribusi komponen teknologi

Tingkat teknologi ditentukan berdasar nilai TCC, dimana tingkat teknologi ada 3 jenis : Tradisional, Semi Modern, Modern.

Tabel 3. Tingkat Teknologi berdasar UN-ESCAP

\begin{tabular}{|c|c|c|}
\hline $0.0<\mathrm{TCC} \leq 0.1$ & Sangat rendah & \multirow{2}{*}{ Tradisional } \\
\hline $0.1<\mathrm{TCC} \leq 0.3$ & Rendah & \multirow{2}{*}{ Semi modern } \\
\hline $0.3<\mathrm{TCC} \leq 0.5$ & Wajar $/$ Sedang & \multirow{2}{*}{ Modern } \\
\hline $0.5<\mathrm{TCC} \leq 0.7$ & Baik & \\
\hline $0.7<\mathrm{TCC} \leq 0.9$ & Sangat baik & \\
\hline $0.9<\mathrm{TCC} \leq 1.0$ & Kecanggihan mutakhir & \\
\hline Sumber $:$ UN-ESCAP & &
\end{tabular}

\section{HASIL DAN PEMBAHASAN}

Hasil temuan yang diperoleh melalui analisa kualitatif berupa paparan deskriptif untuk mendeskripsikan dan menelaah data yang diperoleh melalui observasi langsung dan wawancara kepada informan terpilih selama penelitian berlangsung; yang memang lebih paham permasalahan dan mengerti kondisi eksisting terkait teknologi galangan kapal.

\subsection{Estimasi Level Kecanggihan Komponen Teknologi}

Estimasi level kecanggihan komponen teknologi mengacu prosedur generik dari UN-ESCAP. Setiap komponen teknologi harus ditentukan nilai batas bawah dan atas.

Tabel 4. Rangkuman Hasil Jawaban klasifikasi Komponen Teknologi

\begin{tabular}{|c|l|c|c|c|}
\hline \multirow{2}{*}{$\begin{array}{c}\text { Komponen } \\
\text { Teknologi }\end{array}$} & $\begin{array}{c}\text { Pilihan } \\
\text { Klasifikasi }\end{array}$ & \multicolumn{3}{|c|}{ Batas Nilai } \\
\cline { 3 - 5 } & Bawah & & Atas \\
\hline Technoware & D. Special Purpose Facilities & 4 & 5 & 6 \\
\hline Humanware & D. Reproducing Abilities & 4 & 5 & 6 \\
\hline Infoware & C. Specifying Fact & 3 & 4 & 5 \\
\hline Orgaware & C. Venturing Frameworks & 3 & 4 & 5 \\
\hline
\end{tabular}




\subsubsection{Estimasi Level Kecanggihan Komponen Technoware}

Estimasi level kecanggihan komponen Technoware yaitu Special Purpose Facilities (Fasilitas penggunaaan khusus). Nilai batas bawah adalah 4 dan batas atas adalah 6. Level kecanggihan komponen Technoware diestimasikan pada klasifikasi Special Purpose Facilities (fasilitas penggunaan khusus), dimana saat ini khusus digunakan untuk perlengkapan dalam pembangunan maupun perbaikan kapal, mesin mampu memberi pelayanan otomatis, mudah dioperasikan oleh teknisi dan cukup mengawasi dan siap digunakan.

\subsubsection{Estimasi Level Kecanggihan Komponen Humanware}

Estimasi level kecanggihan komponen Humanware pada klasifikasi Reproducing Abilities (Kemampuan mengelola peralatan). nilai batas bawah adalah 4 dan batas atas adalah 6. Level Kecanggihan Komponen Humanware diestimasikan dalam klasifikasi Kemampuan mengelola peralatan (Reproducing Abilities). Perangkat mesin lebih banyak build up import dari luar negeri, belum ada perangkat tambahan sebagai hasil modifikasi mesin. Teknisi mengelola perangkat mesin agar dapat beroperasi dengan optimal.

\subsubsection{Estimasi Level Kecanggihan Komponen Infoware}

Estimasi level kecanggihan komponen Infoware pada klasifikasi Specifying Fact (Informasi untuk menyeleksi peralatan). nilai batas bawah adalah 3 dan nilai batas atas adalah 5 . Level kecanggihan komponen infoware diestimasikan pada klasifikasi Specifying Fact (Informasi untuk menyeleksi peralatan). Dalam pengoperasian dan pemeliharaan perangkat mesin. Operasional lebih banyak didasarkan kebiasaan yang sudah dijalankan karyawan dengan cara mengikuti kebiasaan sebelumnya tanpa disertai dokumen untuk memahami riwayat kerja mesin.

\subsubsection{Estimasi Level Kecanggihan Komponen Orgaware}

Estimasi level kecanggihan komponen Orgaware pada klasifikasi Venturing Frameworks. nilai batas bawah adalah 3 dan batas atas adalah 5 . Level kecanggihan komponen Orgaware diestimasikan pada klasifikasi Venturing Framework. Saat ini perusahaan sudah mengembangkan jaringan kemitraan bisnis baik dengan perusahaan swasta /industry yang bergerak di bidang penunjang galangan kapal serta dengan asosiasi perkapalan dalam dan luar negeri.

\subsection{Penilaian Tingkat Kemutakhiran Komponen Teknologi}

\subsubsection{Tingkat Kemutakhiran Komponen Technoware}

Untuk menentukan angka penilaian dari tingkat kemutakhiran merupakan hasil identifikasi di lapangan dan wawancara dengan Expert (Informan) terkait Technoware.

Tabel 5. Penilaian Tingkat Kemutakhiran Komponen Technoware

\begin{tabular}{|c|l|c|c|}
\hline No. & Kriteria Technoware & Keterangan & Nilai \\
\hline 1 & Kompleksitas operasi & Otomatis (10);Mekanik (5); Manual (0) & 5 \\
\hline 2 & Presisi / tingkat & Tidak pernah error (10); Rata-rata(5); Sangat rendah(0) & 7 \\
\hline
\end{tabular}


Jurnal Sains Komputer \& Informatika (J-SAKTI)

Volume 3 Nomor 1 Maret 2019, pp. 100-114

ISSN:2548-9771/EISSN:2549-7200

http://tunasbangsa.ac.id/ejurnal/index.php/jsakti

\begin{tabular}{|c|c|c|c|}
\hline No. & Kriteria Technoware & Keterangan & Nilai \\
\hline & ketelitian & $0 \%(10) ; 6-10 \%(5) ; 25 \%(0)$ & 7 \\
\hline 3 & Penanganan bahan & $\begin{array}{c}\text { Pemeliharaan preventif(10); } \\
\text { Sering tapi tidak periodik (5);Tidak dilakukan (0) }\end{array}$ & 5 \\
\hline 4 & Pengendalian proses & Terkomputerisasi(10) ; Manual (5) ; konvensional (0) & 7 \\
\hline 5. & $\begin{array}{l}\text { Kontribusi fasilitas } \\
\text { rekayasa operasional }\end{array}$ & Sangat cepat(10) ; Rata-rata (5); Sangat lambat(0) & 7 \\
\hline \multirow[b]{2}{*}{6} & \multirow[b]{2}{*}{ Kontribusi image/citra } & Teknologi modern $(10)$; rata-rata (5) ; tradisional (0) & 8 \\
\hline & & $\begin{array}{l}\text { Praktis\&ramah lingkungan (10); Kurang praktis \& } \\
\text { ramah lingkungan (5) ; tidak ramah lingkungan (0) }\end{array}$ & 5 \\
\hline \multicolumn{3}{|r|}{ Total Nilai } & 51 \\
\hline \multicolumn{3}{|r|}{ Rata - Rata } & 6,37 \\
\hline
\end{tabular}

Keterangan :

Tingkat kemutakhiran (State of The Art) komponen Technoware adalah :

$$
S T_{i}=\frac{1}{10}\left[\frac{\sum_{k} t_{i k}}{k_{t}}\right]=\frac{1}{10}\left[\frac{51}{8}\right]=0,637
$$

Technoware $(6,37)$ menunjukkan penilaian masih cukup baik, karena masih berada diatas rata-rata $(>=5)$.

\subsubsection{Tingkat Kemutakhiran Komponen Humanware}

Untuk menentukan penilaian merupakan hasil identifikasi dan wawancara berdasar batasan kriteria spesifik terukur pada variabel kriteria Humanware.

Tabel 6. Penilaian Tingkat Kemutakhiran Komponen Humanware

\begin{tabular}{|c|c|c|c|c|}
\hline No & $\begin{array}{c}\text { Kriteria } \\
\text { Humanware }\end{array}$ & $\begin{array}{c}\text { Variabel Kriteria } \\
\text { Humanware }\end{array}$ & Keterangan & Nilai \\
\hline \multirow{2}{*}{1} & \multirow{2}{*}{ Kreatifitas } & $\begin{array}{l}\text { Tingkat inovasi dalam } \\
\text { menyelesaikan masalah }\end{array}$ & $\begin{array}{l}\text { Sangat tinggi(10); Rata-rata } \\
\text { (5);Sangat rendah }(0)\end{array}$ & 5 \\
\hline & & $\begin{array}{l}\text { Kemampuan profesional } \\
\text { melaksanakan pekerjaan }\end{array}$ & $\begin{array}{l}\text { Sangat tinggi (10);Rata- } \\
\text { rata (5);Sangat rendah (0) }\end{array}$ & 5 \\
\hline \multirow{2}{*}{2} & \multirow{2}{*}{$\begin{array}{l}\text { Orientasi } \\
\text { berprestasi }\end{array}$} & $\begin{array}{l}\text { Tingkat pendidikan tenaga } \\
\text { teknis }\end{array}$ & $\begin{array}{c}>30 \%: \text { : SMA (10); } \\
21 \%-30 \% \text { : SMP\&SMA (5); } \\
10 \%-20 \%: \text { SD \& SMP (0) }\end{array}$ & 5 \\
\hline & & $\begin{array}{l}\text { Peningkatan pengalaman } \\
\text { pekerjaan melalui pelatihan }\end{array}$ & $\begin{array}{l}\text { Rutin ada pelatihan }(10) ; \\
\text { Ada tapi tidak rutin(5); } \\
\text { Tidak ada pelatihan }(0)\end{array}$ & 5 \\
\hline 3 & Teamwork & $\begin{array}{l}\text { Kesadaran bekerja dalam } \\
\text { kelompok }\end{array}$ & $\begin{array}{l}\text { Sangat tinggi (10);Rata- } \\
\text { rata (5);Sangat rendah (0) }\end{array}$ & 5 \\
\hline 4. & $\begin{array}{l}\text { Orientasi } \\
\text { pada efisiensi }\end{array}$ & $\begin{array}{l}\text { Kemampuan teknisi } \\
\text { mengelola perangkat teknis }\end{array}$ & $\begin{array}{l}\text { Sangat tinggi (10);Rata- } \\
\text { rata (5);Sangat rendah(0) }\end{array}$ & 7 \\
\hline 5. & $\begin{array}{l}\text { Kemampuan } \\
\text { menghadapi } \\
\text { resiko }\end{array}$ & $\begin{array}{l}\text { Kemampuan inisiatif men } \\
\text { yelesaikan masalah teknis }\end{array}$ & $\begin{array}{l}\text { Sangat tinggi(10); Rata-rata } \\
\text { (5);Sangat rendah }(0)\end{array}$ & 5 \\
\hline 6 & $\begin{array}{l}\text { Tanggung } \\
\text { jawab dan } \\
\text { kedisiplinan }\end{array}$ & $\begin{array}{l}\text { Tanggung jawab dan disiplin } \\
\text { teknisi saat bekerja }\end{array}$ & $\begin{array}{l}\text { Sangat tinggi (10); Rata- } \\
\text { rata (5);Sangat rendah (0) }\end{array}$ & 5 \\
\hline \multicolumn{4}{|c|}{ Total Nilai } & 42 \\
\hline \multicolumn{4}{|c|}{ Rata - Rata } & 5,25 \\
\hline
\end{tabular}

Penilaian Kapabilitas Teknologi Industri Galangan (Satrio Utomo ) | 107 
Keterangan :

Tingkat kemutakhiran (State of The Art) komponen Humanware adalah :

$S H_{j}=\frac{1}{10}\left[\frac{\sum_{l} h_{i j}}{l_{h}}\right]=\frac{1}{10}\left[\frac{42}{8}\right]=0,525$

Humanware $(5,25)$ menunjukkan penilaian masih cukup baik, karena masih berada diatas rata-rata $(>=5)$.

\subsubsection{Tingkat Kemutakhiran Komponen Infoware}

Untuk menentukan penilaian merupakan hasil identifikasi dan wawancara berdasar batasan kriteria spesifik terukur pada variabel kriteria Infoware.

Tabel 7. Penilaian Tingkat Kemutakhiran Komponen Infoware

\begin{tabular}{|c|c|c|c|c|}
\hline No. & $\begin{array}{l}\text { Kriteria } \\
\text { Infoware }\end{array}$ & $\begin{array}{c}\text { Variabel Kriteria } \\
\text { Infoware } \\
\end{array}$ & Keterangan & Nilai \\
\hline \multirow[t]{2}{*}{1} & \multirow[t]{2}{*}{$\begin{array}{l}\text { Kemudahan } \\
\text { pengulangan } \\
\text { informasi }\end{array}$} & $\begin{array}{l}\text { Keberadaan dokumen dan } \\
\text { informasi yang disimpan di } \\
\text { dalam mesin }\end{array}$ & $\begin{array}{c}\text { Sistem File (10); } \\
\text { Dokumen kurang } \\
\text { update(5); Rumit (0) }\end{array}$ & 5 \\
\hline & & $\begin{array}{l}\text { Penyimpanan dan pengambil } \\
\text { an informasi kembali }\end{array}$ & $\begin{array}{l}\text { Terkomputerisasi(10); } \\
\text { Manual(5);Tidak ada(0) }\end{array}$ & 3 \\
\hline 2. & $\begin{array}{l}\text { Keterkaitan } \\
\text { informatif/ } \\
\text { komunikatif }\end{array}$ & $\begin{array}{l}\text { Prosedur dalam komunikasi } \\
\text { antara anggota perusahaan }\end{array}$ & $\begin{array}{c}\text { Mudah dan transparan } \\
\text { (10); Berdasar kepentingan } \\
\text { (5); konvensional }(0) ;\end{array}$ & 3 \\
\hline 3 & $\begin{array}{l}\text { Sistem peng } \\
\text { olahan data }\end{array}$ & $\begin{array}{l}\text { Tersedia aplikasi Sistem } \\
\text { informasi untuk mendukung } \\
\text { aktivitas perusahaan }\end{array}$ & $\begin{array}{l}\text { Akses global (10); } \\
\text { Akses nasional (5); } \\
\text { Tidak ada /lokal (0); }\end{array}$ & 2 \\
\hline 4 & $\begin{array}{l}\text { Kemudahan } \\
\text { komunikasi }\end{array}$ & $\begin{array}{l}\text { Ketersediaan Jaringan } \\
\text { informasi di dalam } \\
\text { perusahaan }\end{array}$ & $\begin{array}{l}\text { Online (10);Online tapi } \\
\text { jaringan tidak stabil(5); } \\
\text { Offline }(0)\end{array}$ & 3 \\
\hline \multirow[t]{2}{*}{5} & \multirow{2}{*}{$\begin{array}{l}\text { Prosedur } \\
\text { suatu } \\
\text { operasional }\end{array}$} & $\begin{array}{l}\text { Log book / Catatan } \\
\text { dokumentasi bila terjadi } \\
\text { kerusakan }\end{array}$ & $\begin{array}{c}\text { Logbook lengkap (10); } \\
\text { Ada logbook tapi tidak } \\
\text { lengkap(5);Tidak ada(0) }\end{array}$ & 3 \\
\hline & & $\begin{array}{l}\text { Petunjuk teknis untuk } \\
\text { pengelolaan perangkat }\end{array}$ & $\begin{array}{c}\text { Ada dan lengkap (10); } \\
\text { Ada tapi tidak lengkap(5); } \\
\text { Tidak pernah }(0)\end{array}$ & 5 \\
\hline 6 & $\begin{array}{l}\text { Kecepatan } \\
\text { akses } \\
\text { informasi }\end{array}$ & $\begin{array}{l}\text { Dukungan perangkat terhadap } \\
\text { kecepatan akses }\end{array}$ & $\begin{array}{l}\text { Sangat tinggi (10); Rata- } \\
\text { rata (5);Sangat rendah (0); }\end{array}$ & 3 \\
\hline \multicolumn{4}{|c|}{ Total Nilai } & 30 \\
\hline \multicolumn{4}{|c|}{ Rata - Rata } & 3,37 \\
\hline
\end{tabular}

Keterangan :

Tingkat kemutakhiran (State of The Art) komponen Infoware adalah :

$S I=\frac{1}{10}\left[\frac{\sum_{m} f_{m}}{m_{f}}\right]=\frac{1}{10}\left[\frac{27}{8}\right]=0,337$

Inforware $(3,33)$ menunjukkan penilaian perlu perhatian, karena masih berada dibawah rata-rata $(<=5)$ 


\subsubsection{Tingkat Kemutakhiran Komponen Orgaware}

Untuk menentukan penilaian merupakan hasil identifikasi dan wawancara berdasar batasan kriteria spesifik terukur pada variabel kriteria Orgaware.

Tabel 8. Keterangan Penilaian Tingkat Kemutakhiran Orgaware

\begin{tabular}{|c|c|c|c|c|}
\hline $\begin{array}{c}\text { No } \\
\text {. }\end{array}$ & $\begin{array}{c}\text { Kriteria } \\
\text { Orgaware }\end{array}$ & $\begin{array}{c}\text { Variabel Kriteria } \\
\text { Orgaware }\end{array}$ & Keterangan & Nilai \\
\hline \multirow[t]{2}{*}{1.} & \multirow{2}{*}{$\begin{array}{l}\text { Efektivitas } \\
\text { Kepemimpinan }\end{array}$} & $\begin{array}{l}\text { Kemampuan memotivasi } \\
\text { kepemimpinan efektif }\end{array}$ & $\begin{array}{l}\text { Sangat tinggi (10);Cukup } \\
\text { (5);Sangat rendah (0); }\end{array}$ & 8 \\
\hline & & $\begin{array}{l}\text { Kemampuan dukungan } \\
\text { sumberdaya dari luar }\end{array}$ & $\begin{array}{l}\text { Sangat tinggi (10);Cukup } \\
\text { (5);Sangat rendah (0); }\end{array}$ & 10 \\
\hline 2. & $\begin{array}{l}\text { Otonomi } \\
\text { pekerjaan }\end{array}$ & Otonomi perusahaan & $\begin{array}{c}\text { Otonomi penuh (10); } \\
\text { Kebijakan dikontrol (5); } \\
\text { Tidak ada Otonomi }(0) ;\end{array}$ & 10 \\
\hline 3. & Arah Organisasi & Visi perusahaan & $\begin{array}{c}\text { berorientasi masa } \\
\text { depan(10); belum ber } \\
\text { orientasi (5); Tidak ada (0); }\end{array}$ & 8 \\
\hline 4 & $\begin{array}{l}\text { Keterlibatan } \\
\text { organisasi }\end{array}$ & $\begin{array}{l}\text { Keterlibatan manajemen } \\
\text { memotivasi karyawan agar } \\
\text { dapat berkembang }\end{array}$ & $\begin{array}{l}\text { Sangat tinggi(10); } \\
\text { mengakomodir (5); } \\
\text { rendah }(0)\end{array}$ & 5 \\
\hline \multirow[t]{2}{*}{5} & \multirow{2}{*}{$\begin{array}{l}\text { Iklim inovasi } \\
\text { dalam organisasi }\end{array}$} & $\begin{array}{l}\text { Kemampuan menciptakan } \\
\text { lingkungan kondusif untuk } \\
\text { peningkatan produktivitas }\end{array}$ & $\begin{array}{l}\text { Sangat tinggi (10); cukup } \\
\text { mengakomodir (5);Sangat } \\
\text { rendah (0) }\end{array}$ & 8 \\
\hline & & $\begin{array}{l}\text { Kemampuan bekerjasama } \\
\text { membangun kemitraan }\end{array}$ & $\begin{array}{c}\text { Interaksi aktif (10); } \\
\text { sifat pasif (5);rendah (0) }\end{array}$ & 5 \\
\hline 6 & $\begin{array}{l}\text { Integritas } \\
\text { tindakan } \\
\text { organisasi }\end{array}$ & $\begin{array}{l}\text { Kemampuan menyesuaikan } \\
\text { diri dengan lingkungan bisnis } \\
\text { yang berubah }\end{array}$ & $\begin{array}{c}\text { Sangat tinggi (10); } \\
\text { cukup menyesuaikan (5); } \\
\text { Sangat rendah }(0)\end{array}$ & 8 \\
\hline \multicolumn{4}{|c|}{ Total Nilai } & 62 \\
\hline \multicolumn{4}{|c|}{ Rata - Rata } & 7,75 \\
\hline
\end{tabular}

Keterangan :

Tingkat kemutakhiran (State of The Art) komponen Orgaware adalah :

$S O_{n}=\frac{1}{10}\left[\frac{\sum_{n} O_{n}}{n_{o}}\right]=\frac{1}{10}\left[\frac{62}{8}\right]=0,775$

Orgaware $(7,75)$ menunjukkan penilaian masih cukup baik, karena masih berada diatas rata-rata $(>=5)$.

\subsection{Penentuan Kontribusi Komponen Teknologi}

Nilai kontribusi merupakan nilai yang dapat digunakan untuk menduga besarnya kontribusi masing-masing komponen teknologi terhadap nilai TCC. Rumus penilaian konstribusi komponen Teknologi :

Nilai konstribusi Technoware adalah :

Batas atas $=6$, batas bawah $=4, S T=0,636$

$$
\begin{gathered}
T=\frac{1}{9}[L T+S T(U T-L T)] ; \mathrm{T}=[4+0,637(6-4)] / 9 \\
=0,565
\end{gathered}
$$

Nilai konstribusi Humanware adalah : 
Batas atas $=6$, Batas bawah $=4$, dan $S H=0,525$

$H=\frac{1}{9}[L H+S H(U H-L H)] ; \mathrm{H} \quad=[4+0,525(6-4)] / 9$

$=0,561$

Nilai konstribusi Infoware adalah :

Batas atas $=5$, Batas bawah $=3$, dan $S I=0,337$

$I=\frac{1}{9}[L I+S I(U I-L I)] ; \quad I=[3+0,337(5-3)] / 9$

$=0,407$

Nilai konstribusi Orgaware adalah :

Batas atas $=5$, Batas bawah $=3$, dan $S O=0,775$

$O=\frac{1}{9}[L O+S O(U O-L O)] ; \quad O=[3+0,775(5-3)] / 9$

$=0,506$

Tabel 9. Hasil Penentuan kontribusi komponen Teknologi

\begin{tabular}{|l|c|c|c|c|}
\hline \multirow{2}{*}{$\begin{array}{c}\text { Komponen } \\
\text { Teknologi }\end{array}$} & \multicolumn{2}{|c|}{ Batas Nilai } & State of The Art \\
(SoTA) & $\begin{array}{c}\text { Kontribusi } \\
\text { Teknologi }\end{array}$ \\
\hline Technoware & 4 & 6 & 0,637 & 0,565 \\
\hline Humanware & 4 & 6 & 0,525 & 0,561 \\
\hline Infoware & 3 & 5 & 0,337 & 0,407 \\
\hline Orgaware & 3 & 5 & 0,775 & 0,506 \\
\hline
\end{tabular}

Pada Tabel diatas memperlihatkan bahwa Komponen teknologi galangan kapal PT.DOK DKB mempunyai porsi kontribusi yang berbeda.Nilai kontribusi komponen teknologi yang tertinggi terdapat pada komponen Technoware.urutankedua adalah Humanware, urutan ketiga adalah Orgaware, dan urutan terakhir adalah Infoware. Kontribusi komponen teknologi bila diurutkan sebagai berikut : $\mathrm{T}>\mathrm{H}>\mathrm{O}>\mathrm{I}$.

\subsection{Penilaian Intensitas Kontribusi Komponen Teknologi $(\boldsymbol{\beta})$}

Deskripsi hasil penilaian Intensitas Kontribusi Komponen Teknologi adalah :

a. Technoware lebih penting dari Humanware.

b. Technoware agak penting dari Infoware.

c. Technoware agak dan lebih penting dari Orgaware.

d. Infoware agak penting dari Humanware.

e. Humanware agak penting dari kemampuan organisasi Orgaware.

f. Infoware sama dan agak penting dari Orgaware. 


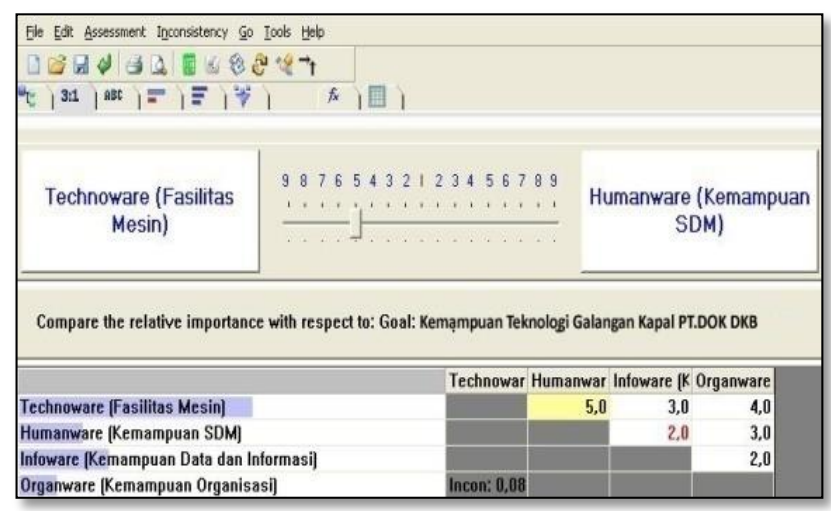

Gambar 2. Tampilan Analisa Data Menggunakan Software Expert Choice

Berdasar analisa menggunakan Software Expert choice berbasis windows, maka didapat Hasil Penilaian intensitas kontribusi teknologi :
a. Technoware $(\beta \mathrm{T})=0,547$
b. Infoware $(\beta \mathrm{I})=0,209$
c. Humanware $(\beta \mathrm{H})=0,152$
d. Orgaware $(\beta 0)=0,091$

Apabila diurutkan, maka nilai rata - rata intensitas masing-masing komponen teknologi sebagai berikut: $\beta \mathrm{T}>\beta \mathrm{I}>\beta \mathrm{H}>\beta \mathrm{O}$

\subsection{Penentuan Koefisien Kontribusi Teknologi (TCC)}

Dengan menggunakan nilai $\mathrm{T}, \mathrm{H}, \mathrm{I}, \mathrm{O}$ dan nilai $\beta$-nya, Technology Coefficient Contribution (TCC) dapat dihitung menggunakan persamaan :

$\mathbf{T C C}=\mathbf{T}^{\boldsymbol{\beta} \mathbf{t}} \cdot \mathbf{H}^{\boldsymbol{\beta} \mathbf{h}} . \mathbf{I}^{\boldsymbol{\beta} \mathbf{i}}, \mathbf{O}^{\boldsymbol{\beta} \mathbf{o}}$

TCC $=0,565^{0,547} \times 0,561^{0,152} \times 0,407^{0,209} \times 0,506^{0,091}$

$=0,519$

Tabel 10. Nilai Koefisien Kontribusi Teknologi (TCC)

\begin{tabular}{|c|c|c|c|c|c|c|c|}
\hline \multirow{2}{*}{$\begin{array}{c}\text { Komponen } \\
\text { Teknologi }\end{array}$} & \multicolumn{2}{|c|}{ Batas } & \multirow{2}{*}{ SOTA } & \multirow[t]{2}{*}{ Penilaian } & \multirow{2}{*}{$\begin{array}{c}\text { Konstribusi } \\
\text { Teknologi }\end{array}$} & \multirow{2}{*}{$\beta$} & \multirow{2}{*}{ TCC } \\
\hline & Bawah & Atas & & & & & \\
\hline Technoware (T) & 4 & 6 & 0,637 & 6,37 & 0,565 & 0,547 & \multirow{4}{*}{0,519} \\
\hline Humanware $(\mathrm{H})$ & 4 & 6 & 0,25 & 5,25 & 0,561 & 0,152 & \\
\hline Infoware (I) & 3 & 5 & 0,337 & 3,37 & 0,407 & 0,209 & \\
\hline Orgaware (0) & 3 & 5 & 0,775 & 7,75 & 0,506 & 0,091 & \\
\hline
\end{tabular}

Pada Tabel 10, memperlihatkan bahwa komponen teknologi galangan kapal mempunyai porsi kontribusi yang berbeda. Kontribusi komponen teknologi tertinggi pada Technoware. Urutan kedua adalah Humanware, urutan ketiga adalah Orgaware, dan urutan terakhir adalah Infoware.Kontribusi tersebut bila diurutkan sebagai berikut : $\mathrm{T}>\mathrm{H}>0>\mathrm{I}$.

Nilai TCC) adalah 0,519. Nilai 0,519 berada interval $0,5<$ TCC $\leq 0.7$ pada klasifikasi Baik dan menunjukkan bahwa tingkat teknologi galangan 
kapal di PT. Dok \& Perkapalan Kodja Bahari (PT.DKB) pada level semi modern.

Berdasar penilaian rata-rata pada variable kriteria komponen teknologi, Technoware $(6,37)$, Humanware $(5,25)$, dan Orgaware $(7,75)$ menunjukkan penilaian yang cukup baik $(>=5)$. Sedangkan Infoware $(3,37)$ menunjukkan penilaian yang kurang baik karena berada dibawah rata-rata (<5), sehingga seharusnya perlu mendapat perhatian untuk dapat ditingkatkan lagi. Untuk mengetahui pemetaan permasalahan berbasis kontribusi masing - masing komponen teknologi galangan kapal terlihat pada gambar 3 .

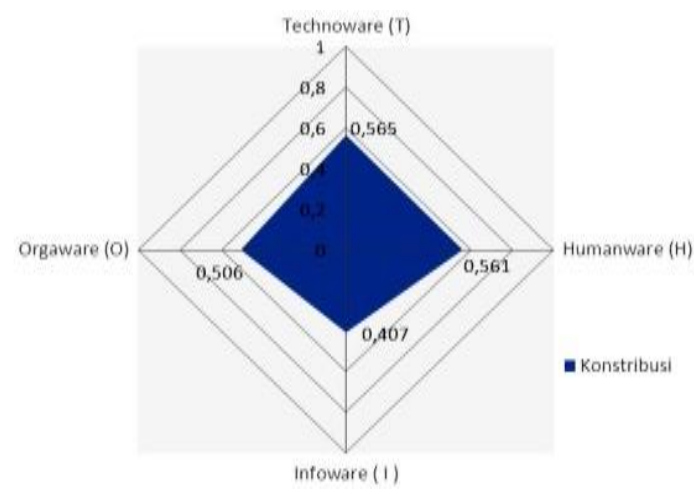

Gambar 3. Diagram Radar Kontribusi Komponen Teknologi

Berdasar gambar 3, terlihat bahwa grafik radar menunjukkan kontribusi komponen teknologi tertinggi adalah Technoware $(0,565)$, urutan berikutnya Humanware $(0,561)$, Orgaware $(0,506)$, dan terkecil adalah Infoware $(0,407)$. Kontribusi tersebut bila diurutkan sebagai berikut : $\mathrm{T}>\mathrm{H}>0>\mathrm{I}$.

Faktor rendah kontribusi komponen Infoware $(0,407)$ bisa disebabkan oleh :

1. Belum ada sistem pendokumentasian data yang baik.

2. Belum ada penerapan SOP (standard Operasional Prosedure) untuk mendukung aktivitas operasional.

3. Belum memaksimalkan sistem informasi manajemen berbasis aplikasi.

Kondisi belum diterapkan sistem pendokumentasian data yang baik bisa disebabkan oleh beberapa hal, antara lain :

a. Belum ada kemauan dari manajemen untuk menyusun dokumentasi petunjuk teknis operasional perangkat mesin.

b. Belum ada kesiapan sarana prasarana mengenai kebutuhan sistem dokumentasi dalam operasional.

c. Belum ada instruksi berupa SOP (Standard Operasional Prosedur) untuk melaksanakan pencatatan aktivitas harian maupun catatan pemeliharaan sebagai bentuk dokumentasi tentang semua pekerjaan operasional yang telah dilakukan pada peralatan tersebut. 
Kondisi belum adanya penerapan SOP (Standard Operasional Prosedur) untuk mendukung aktivitas operasional disebabkan :

a. Operasional keseharian lebih banyak didasarkan pada kebiasaan sebelumnya yang sudah dijalankan tanpa disertai dokumen petunjuk teknis untuk memahami dan mengetahui riwayat kerja mesin.

b. Manajemen perusahaan belum memahami akan pentingnya SOP (Standard Operasional Procedure) untuk kelancaran operasional serta efisiensi pekerjaan tiap karyawan dalam menjalankan pekerjaannya.

c. Setiap ada aktivitas operasional yang berhubungan dengan teknis kerja hanya dikomunikasikan secara lisan saja.

Kondisi masih belum diterapkan sistem informasi manajemen berbasis aplikasi untuk mendukung aktivitas operasional disebabkan oleh:

a. Adanya keterbatasan jumlah dan tingkat kemampuan sumber daya manusia yang khusus mengurusi sistem informasi.

b. Perusahaan lebih menekankan modal perusahaan untuk pengembangan infrastruktur sarana dan prasarana, sehingga pengembangan sistem informasi belum menjadi prioritas perusahaan.

\section{SIMPULAN}

Hasil penilaian teknologi galangan kapal di PT. Dok Kodja Bahari adalah :

a. Tingkat teknologi galangan kapal PT.DOk Kodja Bahari berdasar Technoware, Humanware, Infoware, dan Orgaware adalah level semi modern. Hal ini ditunjukkan dari hasil nilai koefisien kontribusi teknologi galangan kapal adalah 0,519 di interval $0,5<\mathrm{TCC} \leq 0,7$; skala ini pada klasifikasi baik dan menunjukkan tingkatan teknologi level semi modern. Nilai Koefisien Kontribusi Teknologi (TCC) adalah 0,519 sebaiknya menjadi perhatian perusahaan untuk dilakukan perbaikan karena berada dalam batas ambang antara klasifikasi sedang $(0,3<\mathrm{TCC} \leq 0,5)$ dengan klasifikasi baik $(0.5<\mathrm{TCC} \leq 0.7)$. Pengawasan, perbaikan dan pemeliharaan tetap harus terus ditingkatkan, karena menjadi kunci keberhasilan sistem manajemen mutu.

b. Kontribusi komponen teknologi tertinggi adalah Technoware, dan yang terendah adalah Infoware. Hal ini ditunjukkan dari urutan kontribusi yang pertama adalah Technoware $(0,565)$, berikutnya Humanware $(0,561)$, Orgaware $(0,506)$, dan terendah adalah Infoware $(0,407)$. Berdasar hasil penilaian kontribusi komponen teknologi $(\mathrm{T}>\mathrm{H}>0>\mathrm{I})$, Technoware adalah komponen teknologi tertinggi dan Infoware adalah terendah. Sedangkan, berdasar penilaian intensitas kepentingan $(\beta \mathrm{T}>\beta \mathrm{I}>\beta \mathrm{H}>\beta 0)$, Technoware berada di urutan pertama dan Infoware di urutan kedua dalam peningkatan kualitas produk. Sehingga yang perlu disegerakan pengawasan dan perbaikan adalah Technoware dan Infoware. 
c. Upaya peningkatan daya saing industri berdasar urutan prioritas dimulai dari nilai intensitas kontribusi komponen teknologi terbesar, yaitu Technoware, Infoware, Orgaware, Humanware. Hal ini ditunjukkan dari nilai intensitas Technoware $(\beta \mathrm{T}=0,547)$, Infoware $(\beta \mathrm{I}$ $=0,209)$, Humanware $(\beta \mathrm{H}=0,152)$, Orgaware $(\beta \mathrm{H}=0,091)$. Dengan kata lain untuk peningkatan kualitas perusahaan dimulai dari Technoware dengan melaksanakan pemeriksaan, perawatan teratur serta perbaikan sarana prasarana. Dilanjutkan Infoware, dimulai pengembangan sistem informasi dan penyediaan dokumentasi data yang mendukung kinerja organisasi. Dilanjutkan Humanware dengan meningkatkan kompetensi Sumber daya manusia, dan terakhir Orgaware dengan melakukan perbaikan dan penataan manajemen organisasi

\section{DAFTAR PUSTAKA}

[1] Kementerian Perindustrian RI, "Kapasitas Industri Galangan Kapal Nasional Dipacu Naik Tiga Kali Lipat”, Siaran Pers kemenperin tanggal 3 Juli 2018, http://www.kemenperin.go.id/artikel/19400/Kapasitas-Industri-GalanganKapal-Nasional-Dipacu-Naik-Tiga-Kali-Lipat, diakses tanggal 10 februari 2019.

[2] Media Manufaktur Industri,"Kesiapan Indonesia Implementasikan Industri 4.0", News tanggal 28 Juli 2018, https://www.mmindustri.co.id/kesiapanindonesia-implementasikan-industri-4-0/, diakses tanggal 10 Februari 2019

[3] Mohammad Rizal Firmansyah dan Wihdat Djafar,"Tantangan Dalam Implementasi Model Integrasi Industri Perkapalan Di Indonesia", Jurnal Teknik Industri, Vol. 19, No. 1, Februari 2018, pp. 28-37, Februari 2018

[4] Hasbullah, Mansyur,"Strategi Penguatan Galangan Kapal Nasional Dalam Rangka Memperkuat Efektifitas Dan Efisiensi Armada Pelayaran Domestik Nasional 2030",Jurnal Riset dan Teknologi Kelautan (JRTK). Volume 14, Nomor 1, Januari - Juni 2016.

[5] Ahmad Fauzan,"Penilaian Tingkat Teknologi Dok Pembinaan UPT BPTI Muara Angke, Jakarta", Fakultas Pemanfaatan Sumber Daya Perikanan, Institut Pertanian Bogor , Juni 2009

[6] Didik Eko Cahyono,"Teknologi Menggunakan Analytical Hierarchy Process Dan Teknometrik Di Departemen Produksi", Jurnal Teknik Industri vol 14 No.2, Universitas Muhammadiyah Surakarta, Desember 2015

[7] Susihono,"Penilaian teknologi untuk menentukan posisi industri pesaing", J@ti : Jurnal Teknik Industri, 7(2), 131-138, Universitas Diponegoro, Februari 2013 